\title{
Effect of EMS on morpho-physiological characters of wheat in reference to stay green trait
}

\author{
Naresh Pratap Singh* and Vaishali \\ Deptt. of Biotechnology, Sardar Vallabbhai Patel University of Agriculture and Technology, Meerut (U.P), INDIA \\ *Corresponding author. E-mail: naresh.singh55@yahoo.com
}

Received: June 23, 2016; Revised received: February 11. 2017; Accepted: May 9, 2017

\begin{abstract}
To feed the ever growing world population, the demand of food supply must be increased by $70 \%$ of major cereal crops like wheat, rice etc. It was predicted that the detrimental effect of abiotic stresses like drought, heat, salt etc. on yield would be decreased by genetic improvement in terms of photosynthetic response, long green leaf duration and delayed leaf senescence. 'Stay green' is a vital trait of all crops which is directly associated with the capacity of the plant to maintain $\mathrm{CO}_{2}$ assimilation, photosynthesis and chlorophyll content. The present study was conducted to develop the stay green mutants genotype by using $1.5 \%$ Ethyl Methane Sulphonate (EMS). The variety $\mathrm{K} 7410$ showed highest leaf area $37.34 \mathrm{~cm}^{2}$, seeds per spike $65.47,1000$ grain weight $62.03 \mathrm{~g}$ after treatment of EMS among morphological characters observed. Among physiological characters of wheat variety Sonalik showed lowest RWC (21.48 \%), HD 2135 showed lowest chlorophyll content $\left(33.53 \mu \mathrm{g} / \mathrm{cm}^{2}\right)$ and C 306 showed lowest photosynthetic rate $\left(15.05 \mu \mathrm{mol} / \mathrm{m}^{2} \mathrm{sec}\right)$ after treatment of EMS. But varieties $\mathrm{K} 7410, \mathrm{VL} 401$ and RAJ 3765 varieties showed higher value of physiological characters after the treatment. The results suggested that the stay green trait had been developed by mutation (EMS) in these three wheat varieties and they can exhibit better tolerance under abiotic stress conditions like drought, high temperature. Such results would prove useful for further research and crop management in stress affected areas or under unfavourable climatic conditions.
\end{abstract}

Keywords: Chlorophyll, Morphological, Photosynthesis, RWC, Stay green, Wheat

\section{INTRODUCTION}

Today, food security has become a major challenge for all countries to feed up their rapid growing population, so world food supply must be increase by about $70 \%$ by 2050 (Anon, 2009). In recent years, wheat grain requirements of developing countries have increased with $2 \%$ (Donmez et al., 2001; Curtis, 2002). A significant increase in crop productivity will be required to achieve this target using limited cropgrowing areas which is also the major drawback (Parry et al., 2011; Reynolds et al., 2011). Wheat production is highly sensitive to climatic and environmental variations due to global warming (Porter and Semenov, 2005; Sillmann and Roeckner, 2008; Semenov and Shewry, 2011; Lobell, et al., 2012). Increasing temperature and incidence of drought associated with global warming are posing serious threats to food security (Bhullar and Jenner, 1985; Fischer, 1986; Lobell et al., 2013) and challenge to plant breeders and crop scientists who have limited time and resources for improvement in crop production rate (Semenov and Halford, 2009; Foulkes et al., 2011; Zheng et al., 2012).

In recent years, researchers show that some physiological criteria such as stomatal conductance (Bahar et al., 2009), photosynthetic rate (Koc et al., 2003), membran thermal stability (Y1ldirım et al., 2009), canopy tem- perature depression (Bahar et al., 2008), delayed leaf senescence Gregersen et al. (2008) and cholorophyll content (Y1ldirım et al., 2011) provide a gain on wheat production and may be helpful in abiotic stress majorly heat, drought and salt stress tolerance (Reynolds et al., 2001; Balota et al., 2007). Stay green trait induces many morpho-physiological, biochemical and molecular response on plants; so that plants are able to develop tolerance mechanisms which will provide to be adapted to limited environmental conditions (Arora et al., 2002; Bohnert et al., 2006; Shinozaki and Yamaguchi, 2007; Gholamin et al., 2010). Stay green phenotypes maintain green leaf area for a longer period (Spano et al., 2003), maintain $\mathrm{CO}_{2}$ assimilation (Hafsi et al., 2007) under stress conditions. Total flag leaf photosynthesis, chlorophyll content, the onset of senescence and green leaf duration have all been found to be positively correlated with wheat grain yield (Richards, 2000; Kichey et al., 2007; Wang et al., 2008; Gaju et al., 2011). Stay-green describes the delayed senescence during post-anthesis stages of plant development (Thomas and Howarth, 2000) and genetic variation for this trait has been reported in wheat (Hafsi et al., 2007; Falqueto et al., 2009; Srivalli and Khanna-Chopra, 2009). Thomas and Howarth, (2000), described five types of stay-green phenotypes: Type A phenotypes shown late initiation of senescence with a normal 
senescence rate. Type B phenotypes show normal initiation of senescence with a slower rate of senescence. Type $\mathrm{C}$ phenotype shows lesion in chlorophyll degradation, leaving the rest of the senescence process unaffected. Type D phenotype shows rapid death (freeze, boil, dry) ensures maintenance of leaf colour in dead leaf. Type E: enhanced greenness but unchanged initiation and rate of senescence. As a result, the overall process of senescence will take longer to complete. Types A, B, and possibly $\mathrm{E}$ are functionally staygreen: they maintain photosynthetic capacity in their green tissues. Therefore they may be a potential means to improve grain yield. Crops with 'stay green' phenotype such as sorghum has been reported to have increased yield in water limited conditions because they are able to keep their stalk transporting system functioning under severe drought conditions ( $\mathrm{Xu}$ et al., 2000). Many 'stay green' mutants, referred to as functional stay green or non-yellowing in various plant species have been reported to maintain leaf greenness after the grain-ripening stage and give better yield (Fang et al., 1998; Spano et al., 2003). Therefore, this work was aimed to bring light on the most important trait i.e. Stay-Green trait and its major role in improvement in morphological, physiological and biochemical characters for high yield production of wheat under stressed environment.

\section{MATERIALS AND METHODS}

The present research work was carried out at laboratory of Department of Biotechnology, College of Agriculture, of S. V. P. University of Agriculture and Technology, Meerut during rabi season. A total of ten varieties of wheat cultivars viz., HUW 510, C 306, Sonalika, HD 2135, HD 2177, VL 401, K 9162, RAJ 3765 , K 68 , K 7410 were collected to study the effect of EMS treatment on morpho-pysiological and biochemical characters. About 30 seeds of all wheat varieties were soaked in EMS solution $(1.5 \%$ in distill water) for $90 \mathrm{~min}$ in petri plates. Thereafter, the treated seeds of wheat were sown in pots for further collection of data.

Morphological evaluation: The data was observed by randomly selecting five plants from each variety. The data was observed like Plant height $(\mathrm{cm})$, Number of tillers, Leaf Area (of flag leaf), Days of Maturity (days from sowing to the $98-100 \%$ loss of total chlorophyll content of plant, Length of spike $(\mathrm{cm})$, Seeds per Spike (Mean of seeds counted from 5 randomly sampled spikes at maturity is recorded for analysis), Thousand grain weight (in gm.) was recorded from control and treatment plants for comparative study.

Physiological evaluation: After inducing mutation by EMS for developing stay green trait the data for Related Water Content (RWC), Chlorophyll content and Photosynthetic rate was recorded. The RWC was measured on the wheat seedling organs following the method of Turner, (1981). Fresh weight (FW) of flag leaf was determined immediately after harvest, and then tissue were allowed to float in distilled water until fully rehydrated. The wheat organs were weighted for turgid weight (TW). The turgid organs were dried in a hot oven at $80^{\circ} \mathrm{C}$ to constant weight, and dry weight (DW) was recorded. The RWC was calculated as: RW $(\%)=(\mathrm{FW}-\mathrm{DW}) /(\mathrm{TW}-\mathrm{DW}) \times 100$.

Chlorophyll meter (SPAD 520) were used to measures the relative chlorophyll content $\left(\mu \mathrm{gm} / \mathrm{cm}^{2}\right)$ of the leaves and Infra Red Gas Analyzer (IRGA) was used to measure the photosynthetic rate of leaves $(\mu \mathrm{mol} /$ $\mathrm{m}^{2} \mathrm{sec}$ ). Five readings were taken from five plant leaves of same variety and their average was considered for determination of RWC, Chlorophyll content and Photosynthetic rate

Statistical analysis: The experimental data obtained from randomly selected five plants from each replicates were subjected to the statistical analysis outlined by Panse and Sukhatme, (1978). The significance of differences among treatment means was tested by ' $F$ ' test and critical differentiation (at 5 per cent probability) was calculated by the method given by Pearson K. (1895).

\section{RESULTS AND DISCUSSION}

Morphological characterization: In the present study, plant height was recorded at final stage of maturity. The plant height was found to be increased after the treatment of EMS (Table 1, Fig. 1). In control plants, height of plant was varied from $96.15 \mathrm{~cm}$ to $81.57 \mathrm{~cm}$. After treatment Sonalika showed highest plant height $98.83 \mathrm{~cm}$ whereas variety $\mathrm{K} 7410$, RAJ 3765 and VL 401 showed decrement in plant height. The number of productive tillers per plant was varied from 9.58 in K 7410 to 7.47 in HD 2177 in controlled plants The number of productive tillers decreases after all treatments except in K 7410, RAJ 3765 and VL 401 variety. Mean value of flag leaf area was varied from $34.17 \mathrm{~cm}^{2}$ to $24.03 \mathrm{~cm}^{2}$ in variety K 7410 and C 306 in control plants (Table 1, Fig. 1). Total leaf area of flag leaf of wheat varieties was reduced significantly after EMS treatment except in variety HUW 510, VL 401, K 7410 and RAJ 3765 were found to be increased after the EMS treatment. Leaf area of flag leaf is directly related to higher photosynthesis and high chlorophyll content. Genotypes possessing the ability to maintain green leaf area duration (stay green traits) throughout grain filling are potential candidates to assure better yield (Hoang and Kobata, 2009; Larbi and Mekliche, 2004) similarly supporting results were obtained in present study also. After EMS treatment, variety $\mathrm{K}$ 7410, VL 401 and RAJ 3765 took lesser time to get mature after EMS treatment comparatively with others so, it could be considered as better genotype and other showed increament compaired to control (Table 1, Fig. 1). The length of spike varied from $12.33 \mathrm{~cm}$ in $\mathrm{K}$ 
Naresh Pratap Singh and Vaishali / J. Appl. \& Nat. Sci. 9 (2): 1026-1031 (2017)

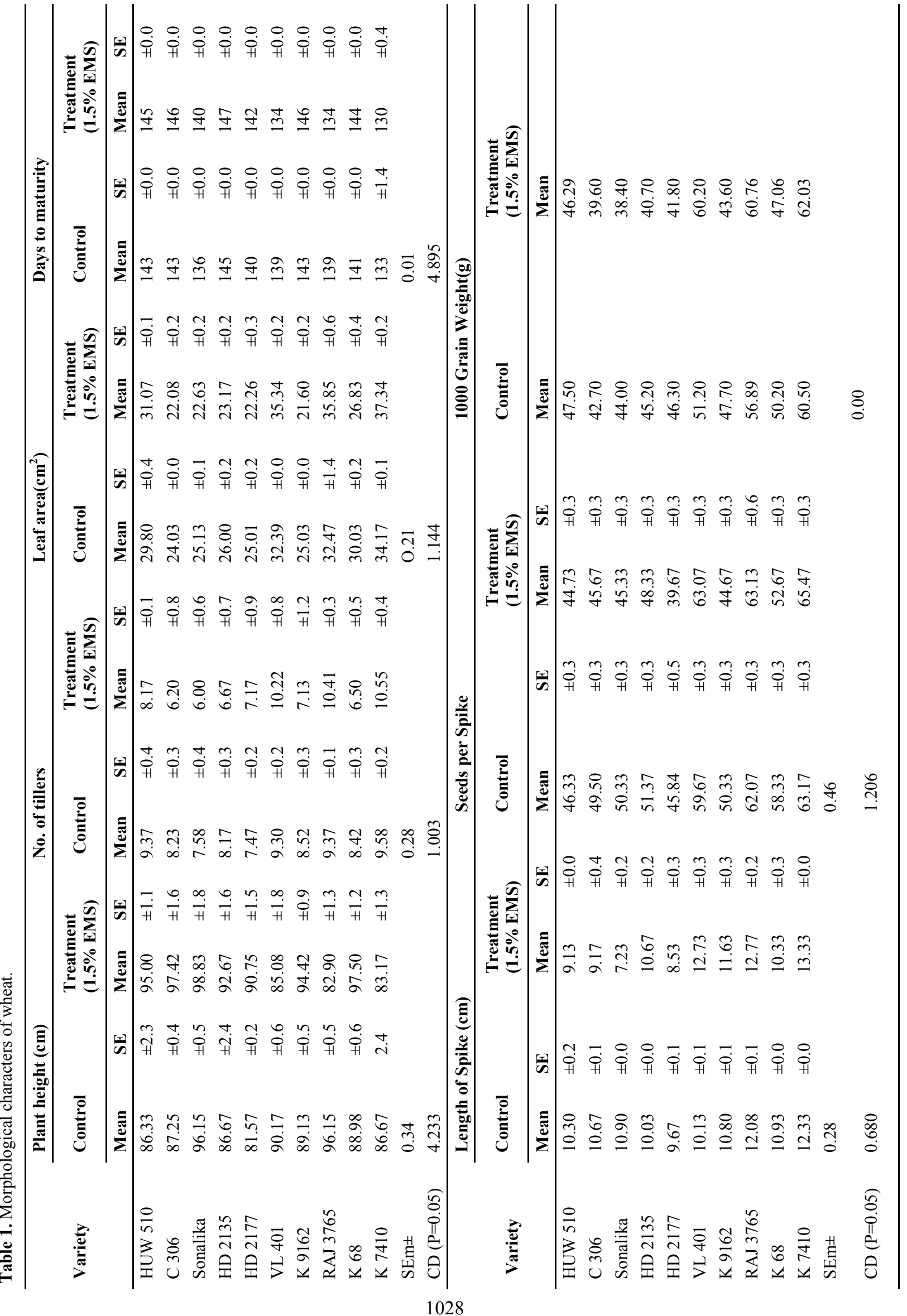


Naresh Pratap Singh and Vaishali / J. Appl. \& Nat. Sci. 9 (2): 1026-1031 (2017)

Table 2. Physiological characters of wheat.

\begin{tabular}{|c|c|c|c|c|c|c|c|c|c|c|c|c|}
\hline \multirow{3}{*}{ Variety } & \multicolumn{4}{|c|}{ RWC(\%) } & \multicolumn{4}{|c|}{ Chlorophyll content $\left(\mu \mathrm{g} / \mathrm{cm}^{2}\right)$} & \multicolumn{4}{|c|}{ Photosynthesis rate $\left(\mu \mathrm{mol} / \mathrm{m}^{2} \mathrm{sec}\right)$} \\
\hline & \multicolumn{2}{|c|}{ Control } & \multicolumn{2}{|c|}{$\begin{array}{c}\text { Treatment } \\
(1.5 \% \text { EMS) }\end{array}$} & \multicolumn{2}{|c|}{ Control } & \multicolumn{2}{|c|}{$\begin{array}{c}\text { Treatment } \\
(1.5 \% \text { EMS) }\end{array}$} & \multicolumn{2}{|c|}{ Control } & \multicolumn{2}{|c|}{$\begin{array}{c}\text { Treatment } \\
(1.5 \% \text { EMS) }\end{array}$} \\
\hline & Mean & SE & Mean & SE & Mean & SE & Mean & SE & Mean & SE & Mean & SE \\
\hline HUW 510 & 60.30 & \pm 0.4 & 54.34 & \pm 0.2 & 43.55 & \pm 2.2 & 40.22 & \pm 1.9 & 16.67 & \pm 0.1 & 15.53 & \pm 0.1 \\
\hline C 306 & 29.43 & \pm 0.2 & 24.41 & \pm 0.2 & 40.10 & \pm 1.2 & 38.57 & \pm 2.1 & 16.17 & \pm 0.3 & 15.05 & \pm 0.3 \\
\hline Sonalika & 26.29 & \pm 0.1 & 21.48 & \pm 0.2 & 38.00 & \pm 1.0 & 34.72 & \pm 0.8 & 18.00 & \pm 0.2 & 16.07 & \pm 0.1 \\
\hline HD 2135 & 55.19 & \pm 0.1 & 52.27 & \pm 0.2 & 36.40 & \pm 2.1 & 33.53 & \pm 2.2 & 17.00 & \pm 0.2 & 16.00 & \pm 0.2 \\
\hline HD 2177 & 36.37 & \pm 0.1 & 32.15 & \pm 0.4 & 39.57 & \pm 2.1 & 32.72 & \pm 0.8 & 18.83 & \pm 0.1 & 17.00 & \pm 0.1 \\
\hline VL 401 & 58.40 & \pm 0.3 & 63.38 & \pm 0.2 & 49.50 & \pm 1.5 & 51.20 & \pm 1.0 & 23.33 & \pm 0.1 & 26.13 & \pm 0.1 \\
\hline K 9162 & 49.49 & \pm 0.2 & 43.34 & \pm 0.2 & 39.57 & \pm 2.1 & 33.07 & \pm 0.6 & 17.70 & \pm 0.1 & 16.00 & \pm 0.2 \\
\hline RAJ 3765 & 60.69 & \pm 0.1 & 63.62 & \pm 0.3 & 49.92 & \pm 1.0 & 51.92 & \pm 1.4 & 23.57 & \pm 0.2 & 26.70 & \pm 0.1 \\
\hline K 68 & 59.44 & \pm 0.2 & 52.23 & \pm 0.3 & 39.03 & \pm 2.2 & 34.40 & \pm 2.1 & 20.13 & \pm 0.1 & 18.67 & \pm 0.3 \\
\hline K 7410 & 62.30 & \pm 0.1 & 65.77 & \pm 0.1 & 50.83 & \pm 1.4 & 54.72 & \pm 1.4 & 24.03 & \pm 0.1 & 28.17 & \pm 0.2 \\
\hline SEm \pm & \multicolumn{4}{|c|}{0.34} & \multicolumn{4}{|c|}{0.46} & \multicolumn{4}{|c|}{0.32} \\
\hline $\mathrm{CD}(\mathrm{P}=0.05)$ & \multicolumn{4}{|c|}{0.739} & \multicolumn{4}{|c|}{0.592} & \multicolumn{4}{|c|}{0.592} \\
\hline
\end{tabular}

7410 to $9.67 \mathrm{~cm}$ in HD 2177 variety in control plants but after treatment of EMS the spike length reduces significantly except in variety K 7410, VL 401 and RAJ 3765 (Table 1, Fig. 2). Seeds per spike are direct measure of yield per plant, hence it is economically important morphological characteristic. The number of seeds per spike was decreasing after EMS treatment in almost all the varieties except in variety $\mathrm{K} 7410$ from (63.17 to 65.47), VL 401 (59.67 to 63.07) and RAJ 3756 (62.07 to 63.13), respectively (Table 1, Fig. 2). 1000 grain weight showed the actual yield of the crop in the field and it varied from $60.50 \mathrm{gms}$ in $\mathrm{K} 7410$ variety to 42.70 gms in C 306 variety in control plants. A significant reduction in 1000 grain weight was observed after treatment of EMS except in variety $\mathrm{K}$ 7410, VL 401 and RAJ 3765 (Table 1, Fig. 2). Similarly, Sparkes (2010) suggested that bread wheat senesces faster than both spelt and emmer which could indicate a 'stay green' trait in it. Many researchers also determined the correlation between yield and flag leaf area duration, explaining that delayed senescence holdup remobilization and leads to reduced grain weight (Rawson et al., 1983; Gregersen et al., 2008).

Physiological characterization: RWC influences the ability of the plant to recover from stress and consequently affects yield. The RWC in controlled plants varied from $62.30 \%$ to $26.29 \%$ in HUW 510, K 7410 and Sonalika (Table 2, figure 3). The increased RWC after EMS treatment was observed in variety $\mathrm{K} 7410$, VL 401 and RAJ 3765 from 62.30 to $65.77 \%, 58.40$ $\%$ to $63.38 \%$ and 60.69 to $63.62 \%$ and thus could be considered as stay green genotype. Keyvan (2010) reported decreased RWC in wheat plants during induced drought stress which affects the growth and yield as well. Matin, (1990) reported in his study that drought tolerant cultivars (barley) usually maintained higher leaf RWC under the stress. Leaf RWC one of the best growth indices revealing the stress intensity for improving yield in wheat (Gupta et al., 2001). The chlorophyll content is one of the essential parameters which also give direct measure of photosynthesis rate and can be considered as indicator of stay green genotypes. In present study, chlorophyll content in control plants varied from $50.83 \mu \mathrm{g} / \mathrm{cm}^{2}$ to $36.40 \mu \mathrm{g} / \mathrm{cm}^{2}$. But after treatment of EMS all varieties showed decline in chlorophyll content from control except variety $\mathrm{K}$ 7410, VL 401 and RAJ 3765 (Table 2, Fig. 3). So these two varieties had not only maximum survival in stressed environment but also give better yield as well. Similar findings were also reported by Khayatnezhad et al. (2011) on Zeamays; Shahriari and Khayatnezhad (2011) on wheat and Adinda et al. (2012) on wheat and concluded that the genotypes with high leaf chlorophyll content are tolerant to abiotic stress conditions. Chlorophyll content of leaf is indicator of photosynthetic capability of plant tissues (Nageswara et al., 2001) studied on Arachishypogaea L. The photosynthesis rate was also found to be increased in $\mathrm{K} 7410$, VL 401 and RAJ 3765 from $24.03 \mu \mathrm{mol} / \mathrm{m}^{2} \mathrm{sec}$ to $28.17 \mu \mathrm{mol} / \mathrm{m}^{2} \mathrm{sec}, 23.33 \mu \mathrm{mol} / \mathrm{m} 2 \mathrm{sec}$ and $23.57 \mu \mathrm{mol} /$ $\mathrm{m}^{2} \mathrm{sec}$ to $26.70 \mu \mathrm{mol} / \mathrm{m}^{2} \mathrm{sec}$, respectively after the treatment of EMS as chlorophyll content but showed a significant reduction in photosynthetic rate after the treatment in other varieties in comparison to control lowest in C 306 (Table 2, Fig. 3). Such profile of photosynthesis rate indicates that variety K 7410, VL 401 and RAJ 3765 could be considered as stay green mutants. The results are consistent with the findings of Michael et al. (2011) on wheat for stay green trait. Extending the duration of photosynthesis is a possible means to increase total photosynthesis, biomass and yield (Richards, 2000). Total flag leaf photosynthesis, chlorophyll content, the onset of senescence (at low nitrogen availability) and green leaf duration directly related with wheat grain yield (Kichey et al., 2007; Wang et al., 2008; Gaju et al., 2011). The findings of Gupta et al., (2001) on wheat also supports the results of the present research work that the stay green trait is directly related to the yield attributes. It means there is a greater scope of using physiological traits coupled with morphological also in selection of better tolerant variety for improving yield in wheat. 


\section{Conclusion}

A key factor to increase wheat yield potential is an extended duration of photosynthetic rate and high chlorophyll content. The yield capacity can be increased if the plant would be able to maintain healthy green area index until the end of grain filling ('stay-green'). In water-limited environments such as $\mathrm{SL}$, improvement in drought tolerance which delays leaf senescence will be essential. The present research results supports that the mutated wheat varieties RAJ 3765, VL 401 and K 7410 can perform better in stressed environment such as drought, high treatment etc. These varieties showed high chlorophyll content $\left(54.72 \mu \mathrm{g} / \mathrm{cm}^{2}\right)$ and photosynthetic rate $(28.17 \mu \mathrm{mol} /$ $\mathrm{m}^{2} \mathrm{sec}$ ) after the treatment of EMS and resulted in high thousand grain weight $(62.03 \mathrm{~g})$. Hence, the stay green trait can be a vital trait for high yield potential of major cereal crops like wheat, rice etc.

\section{REFERENCES}

Adinda, P. D., Simon O., Griffiths, S., Foulkes, M. J. and Malcolm, J. H. (2012). Identification of differentially senescing mutants of wheat and impacts on yield, bio mass and nitrogen partitioning. Journal of Integrative Plant Biology, 54 (8): 555-566

Anon (2009). How to Feed the World in 2050. High-level Experts Forum. FAO, Rome, Pp. 35

Arora, A., Sairam, R. K. and Srivastava, G. C. (2002). Oxidative stress and oxidative system in plants. Curr. Sci., 82: $1227-1238$

Bahar, B., Yildirim, M. and Barutcular, C. (2009). Relationships between stomatal conductance and yield components in spring durum wheat under Mediterranean conditions. Notulae Botanicae Horti Agrobotanici Cluj-napoca., 37(2):45-48

Bahar, B., Yildirim, M., Barutcular, C. and Genc, I. (2008). Effect of canopy temperature depression on grain yield and yield components in bread and durum wheat. Notulae Botanicae Horti Agrobotanici Cluj-napoca., 36 (1): $34-37$

Balota, M., Payne, W.A., Evet, S.R. and Lazar, M.D. (2007). Canopy temperature depression sampling to assess grain yield and genotypic differentiation in winter wheat. Crop Sci., 47: 1518-1529

Bhullar, S.S. and Jenner, C.F. (1985). Differential responses to high temperature of starch and nitrogen accumulation in the grain of four cultivars of wheat. Aust. J. Plant Physiol., 12: 363-75

Bohnert, H. J., Gong, Q., Li, P. and Ma, S. (2006). Unraveling abiotic stress tolerance mechanisms getting genomics going. Curr. Opin. Plant Biol., 9: 180-188

Curtis, B.C. (2002). Wheat in the world. In: Curtis, B. C., Rajaram, S., Macpherson, H. G. (eds.) Bread wheat improvement and production. FAO Plant Production and Protection Series, Rome. Pp. 30

Donmez, E., Sears, R. G., Shroyer, J. P. and Paulsen, G. M. (2001). Genetic gain in yield attributes of winter wheat in the great plains. Crop Sci. Res., 41: 1412-1419

Falqueto, A. R., Cassol, D., De MagalhãesJúnior, M. A., De Oliveira, A. C. and Bacarin, M. A. (2009). Physiological analysis of leaf senescence of two rice cultivars with different yield potential. Pesq. agropec. bras., Brasilia. 44: 695-700

Fang, Z., Bouwkamp, J. C. and Solomos, T. (1998). Chlorophyllase activities and chlorophyll degradation during leaf senescence in the non-yellowing mutant and the wild-type of Phaseolus vulgaris L. J. Exp. Bot., 49:503510

Fischer, R. A. (1986). Physiological limitations to producing wheat in semitropical and tropical environments and possible selection criteria. In: Proc. Int. Sym. Wheat for Tropical Environments. CIMMYT, Mexico. Pp. 209-230

Foulkes, M. J., Slafer, G. A., Davies, W. J., Berry, P. M., Sylvester-Bradley, R., Martre, P., Calderini, D. F., Griffiths, S. and Reynolds, M. P. (2011).Raising yield potential of wheat. III. Optimizing partitioning to grain while maintaining lodging resistance. J. Exp. Bot., 62:469-486

Gaju, O., Allard, V., Martre, P., Snape, J.W., Heumez, E., Le Gouis, J., Moreau, D., Bogard, M., Griffiths, S., Orford, S., Hubbart, S. and Foulkes, M. J. (2011). Identification of traits to improve the nitrogen-use efficiency of wheat genotypes. Field Crops Research., 123: 139-152

Gholamin, R. and Khayatnezhad, M. (2010). Study of some physiological respones of drought stress in hexaploid and tetraploid wheat genotypes in Iran. J. Sci. Res., 6: 246250

Gregersen, P. L., Holm, P. B. and Krupinska, K. (2008).Leaf senescence and nutrient remobilization in barley and wheat. Plant Biology, 10: 37-49

Gupta, N. K., Gupta, S. and Kumar, A. (2001). Effect of water stress on physiological attributes and their relationship with growth and yield of wheat cultivars at different stages. J. Agron. Crop Sci., 186: 55-62

Hafsi, M., Akhter, J. and Monneveux, P. (2007). Leaf senescence and carbon isotope discrimination in durum wheat (Triticum durum desf.) under severe drought conditions. Cereal Research Communications, 35: 71-80

Hoang, T. B. and Kobata, T. (2009). Stay-green in rice (OryzasativaL.) of drought-prone areas in desiccated soils. Plant Production Science, 12: 397-408

Keyvan, S. (2010). The effects of drought stress on yield, relative water content, proline, soluble carbohydrates and chlorophyll of bread wheat cultivars. J. Anim. Plant Sci., 8: 1051-1060

Khayatnezhad, M., Gholamin, R., Jamaati-e-Somarin, S. H. and Zabihie-Mahmoodabad, H. (2011). The leaf chlorophyll content and stress resistance relationship considering in Corn cultivars (Zea mays). Adv. Environ. Biol., 5 (1): 118-122

Kichey, T., Hirel, B., Heumez, E., Dubois, F. and Le Gouis, J. (2007). In winter wheat (Triticumaestivum L.), postanthesis nitrogen uptake and remobilisation to the grain correlates with agronomic traits and nitrogen physiological markers. Field Crops Res., 102: 22-32

Koc, M., Barutcular, C. and Genc, I. (2003). Photosynthesis and productivity of old and modern durum wheats in a Mediterranean Environment. Crop Sci., 43(6):2089-2097

Larbi, A. and Mekliche, A. (2004). Relative water content (RWC) and leaf senescence as screening tools for drought tolerance in wheat. In: Cantero-Martinez C, Cabina D. (Eds.), Mediterranean rainfed agriculture: Strategies for sustainability: Final Seminar of the Regional Action Program on Rainfed Agriculture, 2-3 June 
2003, Zaragoza, Spain. Options Mediterraneennes. Series A, Seminaires Mediterraneens. Paris: International Centre for Advanced Mediterranean Agronomic Studies, 60: 193-196

Lobell, B. D., Sibley, A. and Ortiz-Monasterio, J. I. (2012). Extreme heat effects on wheat senescence in India. Nat. Clim. Change, 2: 186-189

Lobell, D. B., Hammer, G. L., McLean, G., Messina, C., Roberts, M. J. and Schlenker, W. (2013). The critical role of extreme heat for maize production in the United States. Nat. Clim. Change, 3: 497-501

Matin, M. A., Jarvis, H. B. and Hayden, F. (1989). Leaf water potential, relative water content, and diffusive resistant as a screening techniques for drought tolerance in barley. Agron. J., 81: 100-105

Michael O. A., Sparkes, D. L., Parmar, A. and Yawson, D. O. (2011). 'Stay Green' in wheat: comparative study of modern bread wheat and ancient wheat cultivars. ARPN Journal of Agricultural and Biological Science. 6(9):1624

Nageswara, R. R. C., Talwar, H. S. and Wright, G. C. (2001). Rapid assessment of specific leaf area and leaf nitrogen in peanut (Arachishypogaea L.) using chlorophyll meter. J. Agron. Crop Sci., 189:175-182

Panse, V. G. and Sukhatme, P. V. (1978). Statistical methods for agricultural workers ICAR, New Delhi, 145-150

Parry, M. A. J., Reynolds, M., Salvucci, M. E., Raines, C., Andralojc, P. J., Zhu, X. G., Price, G. D., Condon, A. G. and Furbank, R. T. (2011). Raising yield potential of wheat. II. Increasing photosynthetic capacity and efficiency. J. Exp. Bot., 62: 453-467

Pearson, K. (1895). Notes on regression and inheritance in the case of two parents. Proceeding of the Royal Society of London. 58: 240-242

Porter, J. R. and Semenov, M. A. (2005). Crop responses to climatic variation. Phil. Transact. Royal Soc. B-Biol. Sci., 360: 2021-2035

Rawson, H., Hindmarsh, J., Fischer, R. and Stockman, Y. (1983). Changes in leaf photosynthesis with plant ontogeny and relationship with yield per ear in wheat cultivars and 120- progeny. Australian Journal of Plant Physiology, 10: 161-166

Reynolds, M. P., Nagarajan, S., Razzaque, M. A. and Ageeb, O. A. A. (2001). Breeding for adaptation to environmental factors, heat tolerance. In: Reynolds M. P., OrtizMonasterio I., McNab, A. (eds.) Application of physiology in wheat breeding, CIMMYT, Mexico. Pp. 124-125

Reynolds, M., Bonnett, D., Chapman, S. C., Furbank, R. T., Manes, Y., Mather, D. E. and Parry, M. A. J. (2011). Raising yield potential of wheat. I. Overview of a consortium approach and breeding strategies. J. Exp. Bot., 62: 439-452

Richards, R. A. (2000). Selectable traits to increase crop photosynthesis and yield of grain crops. J. Exp. Bot., 51: $447-458$
Semenov, M.A. and Halford, N.G. (2009). Identifying target traits and molecular mechanisms for wheat breeding under a changing climate. J. Exp. Bot., 60: 2791-2804

Semenov, M. A. and Shewry, P. R. (2011). Modelling Predicts that Heat Stress, not Drought, will Increase Vulnerability of Wheat. Europe Scientific Reports 1. Pp. 66

Shahriari, R. and Khayatnezhad, M. (2011). Humiforte application for production of wheat under end seasonal drought stress. Adv. Environ. Biol., 5(1): 141-144

Shinozaki, K. and Yamaguchi-Shinozaki, K. (2007). Gene networks involved in drought stress response and tolerance. J. Exp. Bot., 58: 221-227

Sillmann, J. and Roeckner, E. (2008). Indices for extreme events in projections of anthropogenic climate change. Clim. Change, 86: 83-104

Spano, G., Fonzo, N. Di., Perrotta, C., Platani, C., Ronga, G., Lawlor, D. W., Napier J. A. and Shewry P. R. (2003). Physiological characterization of 'stay green' mutants in durum wheat. Journal of Experimental Botany, 54: 386

Sparkes, D.L. (2010). Are 'ancient wheat species' more adapted to hostile environments than modern bread wheat? South African Journal of Plant and Soil, 27:331334

Srivalli, S. and Khanna-Chopra, R. (2009). Delayed wheat flag leaf senescence due to removal of spikelets is associated with increased activities of leaf antioxidant enzymes, reduced glutathione/oxidized glutathione ratio and oxidative damage to mitochondrial proteins. Plant Physiology and Biochemistry, 47: 663-670

Thomas, H. and Howarth, C. J. (2000). Five ways to stay green. J. Exp. Bot., 51: 329-337

Turner, N.C. (1981). Techniques and experimental approaches for the measurement of plant water status. Plant and Soil, 58: 339-366

Wang, H., McCaig, T. N., DePauw, R. M. and Clarke, J. M. (2008). Flag leaf physiological traits in two highyielding Canada Western Red Spring wheat cultivars. Can. J. Plant Sci., 88: 35-42

$\mathrm{Xu}$, W., Rosenow, D.T. and Nguyen, H.T. (2000). Staygreen trait in grain sorghum: Relationship between visual rating and leaf chlorophyll concentration. Plant Breeding, 119: 365-36

Yıldırım, M., Bahar, B., Koç, M., Barutçular, C. (2009). Membrane thermal stability at different developmental stages of spring wheat genotypes and their diallel cross populations. Tarim Bilimleri Dergisi., 15(4): 293- 300

Yildırım, M., Kılic, H., Kendal, E. and Karahan, T. (2011). Applicability of chlorophyll meter readings as yield predictor in durum wheat. J. Plant Nutr., 34(2): 151-164

Zheng, B., Chenu, K., Dreccer, M. F. and Chapman, S. C. (2012). Breeding for the future: what are the potential impacts of future frost and heat events on sowing and flowering time requirements for Australian bread wheat (Triticumaestivium) varieties? Glob. Change Biol., 18: 2899-2914 